\title{
THE EFFECT OF VARIOUS CATIONS ON THE WATERSTABILITY OF SOIL AGGREGATES
}

\author{
Mikko SillanpäÄ \\ Department of Soil Science, Agricultural Research Centre, Helsinki
}

Received July 20, 1960

Formation of the structure in different soils depends largely on the organic matter content and texture of soils. However, the chemical properties of soils, especially the role of cations has been found to be important in stabilizing soil aggregates. Because of the electronegative character of soil colloids the effect of anions seems to be less important in aggregate formation. Improvements of soil structure produced by $\mathrm{N}$ and $\mathrm{P}$ have been noticed which, however, may be indirectly due to their favourable effect on herbage yield (10). The increase of aggregate stability that was caused by the $\mathrm{NH}_{3}$ treatment, however, was found to be only for a short duration emphasizing the dynamic nature of soil aggregate stability (5).

KATschinski (9) has summarized the results of several investigators concerning the ability of cations to coagulate soil colloids as follows: $\mathrm{Fe}^{+++}>\mathrm{Al}^{+++}>\mathrm{Ba}^{++}>$ $\mathrm{Sr}^{++}>\mathrm{Ca}^{++}>\mathrm{Mg}^{++}>\mathrm{K}^{+}>\mathrm{Na}^{+}>\mathrm{Li}^{+}$. Hydrogen, even though monovalent, comes after calcium or it may even be more effective. The order of coagulation effect of $\mathrm{Ca}^{++}, \mathrm{Mg}^{++}, \mathrm{K}^{+}$and $\mathrm{Na}^{+}$in Finnish heavy clay soils was the same as above (21). In the study of MAzURAK (12) the order of the geometric mean diameters of Hesperia soil aggregates formed with different cations was found to be associated with the hydration of ions: $\mathrm{H}^{+}>\mathrm{Cs}^{+}>\mathrm{Rb}^{+}>\mathrm{NH}_{4}^{+}>\mathrm{K}^{+}>\mathrm{Na}^{+}>\mathrm{Li}^{+}$. In this soil the presence of $\mathrm{Ca}^{++}$in the aggregates decreased the water stability progressively with increasing concentrations of $\mathrm{Ca}^{++}$within the aggregates. It was concluded that changes in salt composition and salt concentration of irrigation water affect the dispersion of aggregates. In many soils, however, liming has been found to improve the structural stability of aggregates (15, 17 etc.) CzEratzKI (3) assumed that the effect of lime is a direct coagulationg effect rather than a stimulation of biologial processes. Homrighausen (7) states that because increasing amounts of $\mathrm{CaCO}_{3}$ increased the stability of aggregates in very fine soils but not in coarser soils it was possibly. due to bridge formation through fine soil and lime particles.

According to Filippovich (4) the good structure of calcareous soils, such as chernozems and rendzinas, is a result of their high Fe content. The favourable effect 
of calcium on soil structure is based on its converting effect of soluble Fe salts into colloidal insoluble hydrated $\mathrm{Fe}_{2} \mathrm{O}_{3}$. Further, the stable structure of acid soils unsaturated with bases but rich in hydrated $\mathrm{Fe}_{2} \mathrm{O}_{3}$ and humus is not due to humus accumulation unless accompanied by accumulation of colloidal hydrated $\mathrm{Fe}_{2} \mathrm{O}_{3}$. In many tropical and subtropical soils the silt and clay are cemented into "pseudo sand" by iron hydroxide (5). According to LEvin (11) liming decreases the stability of acid podsolic soil aggregates soon after application by decreasing the content of mobile sesquioxides but later, owing to Ca-humate formation, the stability increases. ChEsters et al. (2) found iron as an important factor in aggregate formation in all of the four Wisconsin soils studied. They also found that at $\mathrm{pH}$ range $4-8$ an optimum $\mathrm{pH}$ occurred for soil aggregation at approximately $\mathrm{pH}$ 6.5. In some Sardinian soils an inverse correlation between $\mathrm{pH}$ and structural stability was noticed (13).

In the investigation of RoBINSON and PAGE (16) hydrogen ion proved to be much more effective in aggregate stabilization than the other cations tested. Sodium caused the most slaking. There are different opinions about the role of exchangeable magnesium in aggregate formation. The poor physical properties of some Havaiian soils rich in exchangeable magnesium were believed to be a result of the hydration of the exchangeable magnesium ion in the presence of certain humates resulting in a dispersion of the clay and organic matter (6). JofFe and Zimmerman (8) have concluded that magnesium has an effect similar to that of sodium but in the study of BROoKs et al. (1) magnesium acted more like potassium and calcium. From the literature it is evident that the effect of various cations is not similar in all soils but depends upon the conditions and soil constituents present.

\section{Materials and methods}

Muddy clay (or gyttja clay) soils are generally low in bases, high in sulphur and very acid. The average content of $\mathrm{CaCO}_{3}, \mathrm{~K}_{2} \mathrm{O}$ and $\mathrm{S}$ are 1,5 to/ha, $486 \mathrm{~kg} / \mathrm{ha}$ and $3872 \mathrm{~kg} / \mathrm{ha}$ respectively and average pH 3.9 (14). The physical properties of muddy clays are good; the average mean weight diameter of water stable aggregates and also the average hydraulic conductivity was highest among the Finnish soil types studied by SILLANPÄ $(19,20)$. To make these soils more productive they require very large amounts of lime and fertilizers. Thus their chemical properties will be essentially changed. Because of this muddy clay was selected for investigating the effect of cations on aggregation. Also analyses with a heavy, loamy and silty clay soils are included in this study for comparative purposes.

Large homogeneous soil samples were spread as a thin layer, larger clods were crushed gently by hand and the soils were allowed to become air dry. In experiments with heavy, silty and loamy clays the soils were previously dry-sieved with $2 \mathrm{~mm}$ and $1.3 \mathrm{~mm}$ screens to obtain an aggregate fraction of $1.3-$ $2.0 \mathrm{~mm}$ for analyses. In the case of the better aggregated muddy clay soil, however, $2.2-3.5 \mathrm{~mm}$ aggregates were selected.

Samples of 25 grams were weighed in $50 \mathrm{ml}$ dishes over a $2 \mathrm{~cm}$ wide cloth (Fig. 1). The samples were wetted by submerging one end of the cloth in the wetting solution as shown in Fig. 1, A, and allowing the solution to pass along the cloth into the other dish to moisten the soil sample slowly by capillarity. The samples were left in a submerged condition for two days, after which the excess solution above the soil was poured away and the rest of the solution was drained from the soil by raising the dish containing the sample on a stage (Fig. 1, B). The samples were air dried in open dishes. The forma tion of fungus vegetation on soil was prevented and the drying process accelerated by placing lamps above the dishes. The temperature during the drying process was kept $28-31^{\circ} \mathrm{C}$. 
A

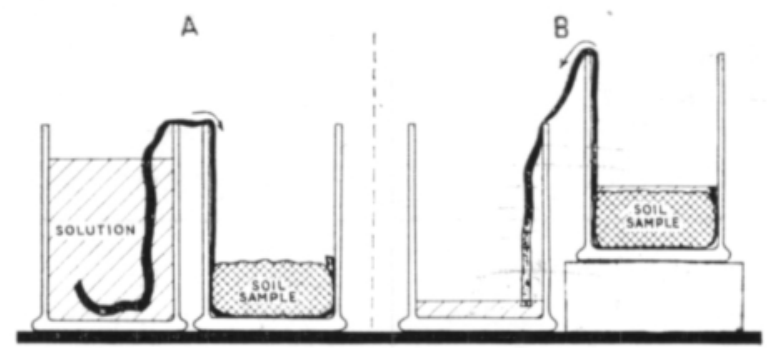

Fig. 1. Wetting a soil sample by capillarity along a ribbon of cloth (A) and removing of excess liquid from the sample (B).

The solutions used in the experiments with heavy, silty and loamy clays were $0.01-\mathrm{N} \mathrm{HCl}, \mathrm{Na}, \mathrm{K}$, $\mathrm{Mg}$ and $\mathrm{Ca}$ chlorides and distilled water as a check. In the case of the muddy clay soil the experiments

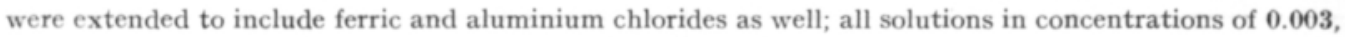
$0,01,0.03,0.1$ and $0.3-\mathrm{N}$.

On the seventh day after drying the samples were rewet by the above mentioned method with distilled water, poured into $500 \mathrm{ml}$ shaking bottles containing $400 \mathrm{ml}$ distilled water and shaken for 5 minutes at 30 r.p.m. Then the soil samples were poured on the uppermost sieves of the wet sieving apparatus (18) and sieved for $\mathbf{3 0}$ minutes at $\mathbf{3 0}$ oscillations per minute.

\section{Results and discussion}

The results of aggregate analyses after different treatments are given in tables 1 and 3 and the regressions concerning muddy clay soil in table 4 and in Fig. 2. Statistical significances of the differences between the treatments are given in table 2 (heavy clay; $0.01-\mathrm{N}$ solutions and destilled water) and in table 5 (muddy clay 0.01 and $0.03-\mathrm{N}$ solutions and destilled water).

In the heavy clay soil hydrogen and calcium have improved the structural stability of soil most effectively. Their effect exceeds significantly those of all other cations except that of magnesium (table 2). Also the influence of magnesium is relatively clear with significantly better aggregation than with the check soil (dist.

Table 1. Mean weight diameters of aggregates ( $\mathrm{mm}$; mean and standard deviation) of three clay soils after treatments with distilled water and various $0.01-\mathrm{N}$ chloride solutions.

\begin{tabular}{|c|c|c|c|c|c|c|}
\hline Soil type & Dist. water & $\begin{array}{c}\mathrm{NaCl} \\
(0.01-\mathrm{N})\end{array}$ & $\begin{array}{c}\mathrm{KCl} \\
(0.01-\mathrm{N})\end{array}$ & $\begin{array}{l}\mathrm{MgCl}_{2} \\
(0.01-\mathrm{N})\end{array}$ & $\begin{array}{c}\mathrm{CaCl}_{2} \\
(0.01-\mathrm{N})\end{array}$ & $\begin{array}{c}\mathrm{HCl} \\
(0.01-\mathrm{N})\end{array}$ \\
\hline \multirow[t]{2}{*}{ Heavy clay } & 0.993 & 1.027 & 1.060 & 1.087 & 1.105 & 1.114 \\
\hline & \pm 0.074 & \pm 0.010 & \pm 0.028 & \pm 0.011 & \pm 0.019 & \pm 0.040 \\
\hline \multirow[t]{2}{*}{ Silty clay } & 1.022 & 1.019 & 1.045 & 1.045 & 1.049 & 1.046 \\
\hline & \pm 0.044 & \pm 0.033 & \pm 0.031 & \pm 0.028 & \pm 0.037 & \pm 0.031 \\
\hline \multirow[t]{2}{*}{ Loamy clay } & 0.881 & 0.885 & 0.939 & 0.939 & 0.960 & 0.958 \\
\hline & \pm 0.058 & \pm 0.069 & \pm 0.085 & \pm 0.054 & \pm 0.043 & \pm 0.065 \\
\hline
\end{tabular}


Table 2. Statistical significance of the differences (t-values) in aggregate stability of a heavy clay soli after treatments with distilled water and various $0.01-\mathrm{N}$ solution (significances at $10^{*}, 5^{*}, 1^{* *}$ and $0.1^{* * *}$ per cent levels).

\begin{tabular}{lccccc}
\hline & $\mathrm{NaCl}$ & $\mathrm{KCl}$ & $\mathrm{MgCl}_{2}$ & $\mathrm{CaCl}_{2}$ & $\mathrm{HCl}$ \\
\hline & & & & & \\
\hline $\mathrm{H}_{2} \mathrm{O}$ & 0.92 & 1.68 & $2.54^{*}$ & $2.95^{*}$ & $2.88^{*}$ \\
$\mathrm{NaCl}$ & - & $2.20^{*}$ & $8.57^{* * *}$ & $7.09^{* * *}$ & $4.14^{* *}$ \\
$\mathrm{KCl}$ & & - & 1.80 & $2.65^{*}$ & $2.25^{*}$ \\
$\mathrm{MgCl}_{2}$ & & & - & 1.64 & 1.29 \\
$\mathrm{CaCl}_{2}$ & & & - & 0.41
\end{tabular}

Table 3. Mean weight diameters of the muddy clay soil aggregates (mm; mean and standard deviation) after treatments with different solutions.

\begin{tabular}{|c|c|c|c|c|c|c|}
\hline \multirow[b]{2}{*}{ Solution } & \multicolumn{5}{|c|}{ Normality of solution } & \multirow[b]{2}{*}{0.3} \\
\hline & $\begin{array}{c}0.000 \\
\left(\mathrm{H}_{2} 0\right)\end{array}$ & 0.003 & 0.01 & 0.03 & 0.1 & \\
\hline $\mathrm{NaCl}$ & $\begin{array}{r}1.725 \\
+0.060\end{array}$ & $\begin{array}{r}1.805 \\
\pm 0.192\end{array}$ & $\begin{array}{r}1.835 \\
+0.152\end{array}$ & $\begin{array}{r}1.703 \\
+0.147\end{array}$ & $\begin{array}{r}1.630 \\
+0.059\end{array}$ & $\begin{array}{r}1.470 \\
\pm 0.042\end{array}$ \\
\hline $\mathrm{KCl}$ & $\begin{array}{r}1.717 \\
\pm 0.090\end{array}$ & $\begin{array}{r}1.736 \\
+0.137\end{array}$ & $\begin{array}{r}1.790 \\
+0.168\end{array}$ & $\begin{array}{r}1.800 \\
\pm 0.142\end{array}$ & $\begin{array}{r}1.896 \\
\pm 0.091\end{array}$ & $\begin{array}{r}1.753 \\
\pm 0.100\end{array}$ \\
\hline $\mathrm{MgCl}_{2}$ & $\begin{array}{r}1.728 \\
\pm 0.090\end{array}$ & $\begin{array}{r}1.838 \\
\pm 0.139\end{array}$ & $\begin{array}{r}1.933 \\
\pm 0.116\end{array}$ & $\begin{array}{r}1.930 \\
\pm 0.110\end{array}$ & $\begin{array}{r}1.823 \\
\pm 0.076\end{array}$ & $\begin{array}{r}1.583 \\
+0.057\end{array}$ \\
\hline $\mathrm{CaCl}_{2}$ & $\begin{array}{r}1.720 \\
\pm 0.129\end{array}$ & $\begin{array}{r}1.853 \\
+0.206\end{array}$ & $\begin{array}{r}1.855 \\
+0.281\end{array}$ & $\begin{array}{r}1.900 \\
\pm 0.220\end{array}$ & $\begin{array}{r}1.873 \\
\pm 0.182\end{array}$ & $\begin{array}{r}1.733 \\
\pm 0.094\end{array}$ \\
\hline $\mathrm{AlCl}_{3}$ & $\begin{array}{r}1.660 \\
+0.010\end{array}$ & $\begin{array}{r}1.910 \\
+0.017\end{array}$ & $\begin{array}{r}2.016 \\
+0.035\end{array}$ & $\begin{array}{r}2.093 \\
\pm 0.101\end{array}$ & $\begin{array}{r}2.206 \\
\pm 0.106\end{array}$ & $\begin{array}{r}2.060 \\
\pm 0.161\end{array}$ \\
\hline $\mathrm{FeCl}_{3}$ & $\begin{array}{r}1.663 \\
\pm 0.067\end{array}$ & $\begin{array}{r}1.793 \\
+0.162\end{array}$ & $\begin{array}{r}2.096 \\
+0.107\end{array}$ & $\begin{array}{r}2.103 \\
+0.182\end{array}$ & $\begin{array}{r}2.193 \\
+0.120\end{array}$ & $\begin{array}{r}1.943 \\
+0.160\end{array}$ \\
\hline $\mathrm{HCl}$ & $\begin{array}{r}1.745 \\
+0.267\end{array}$ & $\begin{array}{r}1.848 \\
\pm 0.065\end{array}$ & $\begin{array}{r}1.853 \\
\pm 0.094\end{array}$ & $\begin{array}{r}1.775 \\
\pm 0.120 \\
\end{array}$ & $\begin{array}{r}1.658 \\
\pm 0.063\end{array}$ & $\begin{array}{r}1.573 \\
\pm 0.093\end{array}$ \\
\hline Average & $\begin{array}{r}1.712 \\
+0.120\end{array}$ & $\begin{array}{l}- \\
-\end{array}$ & $\begin{array}{l}- \\
-\end{array}$ & - & - & - \\
\hline
\end{tabular}

water) and sodium. The significance, however, may be more due to the small standard deviation rather than the difference between the mean values of MwDA.

In the silty clay and loamy clay soils the order of the effects of the cations is mainly the same as in the heavy clay. In these soils the similar effects of potassium and magnesium should be noted. This is similar to the results of Brooks et al. (1). 
Table 4. Regressions of the mean weight diameter of aggregates $(\mathrm{Y}, \mathrm{mm})$ in the muddly clay soil on the normality of the treatment solution $(\mathrm{X}),(\mathrm{R}=$ correlation coefficient).

Solution

$\begin{array}{llll}\mathrm{NaCl} & \mathrm{Y}=1.22-0.523 \log \mathrm{X}-0.1171(\log \mathrm{X})^{2} & 0.60^{* *} \\ \mathrm{KCl} & \mathrm{Y}=1.74-0.123 \log \mathrm{X}-0.0461(\log \mathrm{X})^{2} & 0.68^{* *} \\ \mathrm{MgCl}_{2} & \mathrm{Y}=1.28-0.702 \log \mathrm{X}-0.1866(\log \mathrm{X})^{2} & 0.62^{* *} \\ \mathrm{CaCl}_{2} & \mathrm{Y}=1.58-0.369 \log \mathrm{X}-0.1073(\log \mathrm{X})^{2} & 0.53^{* *} \\ \mathrm{AlCl}_{3} & \mathrm{Y}=1.96-0.327 \log \mathrm{X}-0.1413(\log \mathrm{X})^{2} & 0.78^{* * *} \\ \mathrm{FeCl}_{3} & \mathrm{Y}=1.75-0.557 \log \mathrm{X}-0.2007(\log \mathrm{X})^{2} & 0.81^{* * *} \\ \mathrm{HCl} & \mathrm{Y}=1.34-0.454 \log \mathrm{X}-0.1041(\log \mathrm{X})^{2} & 0.59^{* *}\end{array}$

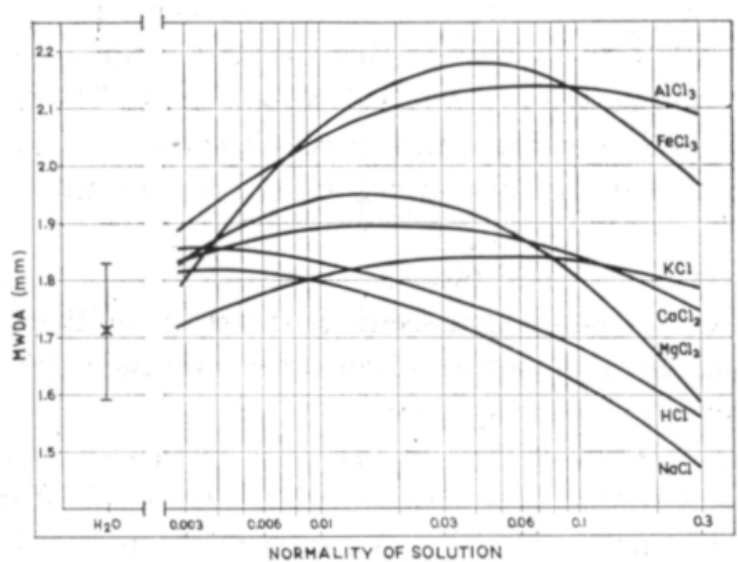

Fig. 2. Regressions of the mean weight diameter of aggregates (MWDA, mm) in the muddy clay soil on the concentration of various treatment solutions. In the case of distilled water treatment the mean and standard deviation are given.

Table 5. Statistical significance of the differences (t-values) between the results of aggregate analyses from the muddy clay soil after treatments with distilled water, $0.01-\mathrm{N}$ and $0.03-\mathrm{N}$ solutions. The t-values for the last mentioned concentration are given within parantheses. (Significances at $10^{*}, 5^{*}, 1^{* *}$, and $0.1^{* * *}$ per cent levels).

\begin{tabular}{|c|c|c|c|c|c|c|c|c|}
\hline & $\mathrm{H}_{2} \mathrm{O}$ & $\mathrm{NaCl}$ & $\mathrm{KCl}$ & $\mathrm{MgCl}_{2}$ & $\mathrm{CaCl}_{2}$ & $\mathrm{AlCl}_{3}$ & $\mathrm{FeCl}_{3}$ & $\mathrm{HCl}$ \\
\hline $\mathrm{H}_{2} \mathrm{O}$ & - & 1.54 & 0.78 & $3.52 * *$ & 1.00 & $9.68 * * *$ & $5.79 * * *$ & $2.67^{*}$ \\
\hline $\mathrm{NaCl}$ & $(0.12)$ & - & 0.37 & 1.02 & 0.40 & $2.30^{\circ}$ & $2.66^{*}$ & 0.20 \\
\hline $\mathrm{KCl}$ & $(1.03)$ & $(0.88)$ & - & 1.27 & 0.38 & $2.28^{\circ}$ & $2.66^{*}$ & 0.58 \\
\hline $\mathrm{MgCl}_{2}$ & $\left(3.63^{* *}\right)$ & $\left(2.47^{*}\right)$ & $(1.32)$ & - & 0.51 & 1.35 & 1.92 & 1.07 \\
\hline $\mathrm{CaCl}_{2}$ & $(1.67)$ & $(1.49)$ & $(0.73)$ & $(0.24)$ & - & 1.14 & 1.57 & 0.13 \\
\hline $\mathrm{AlCl}_{3}$ & $(6.04 * * *)$ & $\left(4.16^{* *}\right)$ & $\left(2.91^{*}\right)$ & $\left(2.03^{\circ}\right)$ & $(1.55)$ & - & 0.92 & $3.19^{*}$ \\
\hline $\mathrm{FeCl}_{3}$ & $(3.63 * *)$ & $\left(3.12^{*}\right)$ & $\left(2.27^{\circ}\right)$ & $(1.46)$ & (1.33) & $(0.08)$ & - & $3.13^{*}$ \\
\hline $\mathrm{HCl}$ & $(0.97)$ & $(0.76)$ & $(0.25)$ & $(1.90)$ & $(1.00)$ & $\left(3.80^{*}\right)$ & $\left(2.71^{*}\right)$ & - \\
\hline
\end{tabular}


In the case of silty clay the differences between treatments did not reach any statistical significance and in loamy clay there were statistically significant differences only between $\mathrm{H}_{2} \mathrm{O}-\mathrm{CaCl}_{2}\left(\mathrm{t}=2.47^{*}\right), \quad \mathrm{H}_{2} \mathrm{O}-\mathrm{HCl} \quad(\mathrm{t}=1.97 \cdot)$ and $\mathrm{NaCl}-\mathrm{CaCl}_{2}$ $\left(\mathrm{t}=2.08^{*}\right)$.

Generally, with increasing solution concentrations in the muddy clay soil (table 3, and Fig. 2) all cations initially improved the structural stability. When the concentration of solutions was further increased the effect of all cations gradually changed to dispersion. The highest solution concentrations used in treatments apparently caused changes in soil cation composition to such a degree that it produced a dispersion. MazuraK (12) similarly concluded that changes in salt composition and concentration of irrigation water may affect the dispersion of aggregates.

Different cations seem to reach their optimum effects in different concentrations. For $\mathrm{NaCl}, \mathrm{HCl}$ and $\mathrm{MgCl}_{2}$ the optimum normality seems to lie around $0.01-\mathrm{N}$, for $\mathrm{CaCl}_{2}$ from 0.01 to $0.03-\mathrm{N}$ and for $\mathrm{KCl}, \mathrm{AlCl}_{3}$ and $\mathrm{FeCl}_{3}$ the optimum aggregation is first reached with approximately $0.03-0.1-\mathrm{N}$ solutions. The shape of the regression curve of potassium differs from other curves because of its milder curvilinearity; i.e. it seems that potassium affects aggregation less than the other cations under study.

Aluminium and iron have had the strongest stabilizing effect on the muddy clay aggregates. The effect of magnesium seems to be stronger than that of calcium in milder concentrations but with increasing concentration the regression line of magnesium turns more steeply toward dispersion.

As an interesting feature it can be seen that in this soil the regression line of $\mathrm{HCl}$ corresponds closely to that of sodium, which has the weakest stabilizing capacity. In this respect the influence of $\mathrm{HCl}$ differs considerably from that in other clay soils studied.

This shows, as already seen from the literature, that a cation may play different roles in different soils thus limiting considerably the application of results from one soil to another.

\section{$S u m m$ ary}

The effects of various cations on the aggregation of four clay soils were studied. To avoid errors and variation and to obtain clear differences between the treatments only certain limited size fractions of aggregates were used. The samples were wetted slowly by capillarity with the treatment solutions, allowed to stand in a submerged condition, air-dried, rewetted and analyzed by the wet sieving method.

The results bring out rather distinct differences among the effects of various cations. The water stability of aggregates was a function of the concentration of the treatment solutions.

\section{REFERENCES}

(1) Brooks, R. H., Bower, C. A. \& Reeve, R. C. 1956. The effect of various exchangeable cations upon the physical condition of soils. Soil Sci. Soc. Amer. Proc. 20: 325-327.

(2) Chesters, G., Attoe, O. J. \& Allen, O. N. 1957. Soil aggregation in relation to various soil constituents. Ibid. 21: $272-277$. 
(3) Czeratzkı, W. 1957. Untersuchungen über Krümelstabilität an einem Kalkversuch. Z. Pfl. Ern. u. Düng. 78: 121-135.

(4) Filip povich, Z. S. 1956. [Absorption of colloids by soils and the formation of structure]. Pochvovedenie N:o 2: 16-26 (Ref. Soils Fert. 19: p. 333).

(5) Gifford, R. O. \& Strickling, E. 1958. The effect of anhydrous ammonia on water stability of soil aggregates. Soil Sci. Soc. Amer. Proc. 22: 209-212.

(6) Gill, W. R. \& Sherman, G. D. 1952. Properties of the gray hydromorphic soils of the Hawaiian Islands. Pac. Sci. 6: 137 (Ref. Soils Fert. 15: p. 297).

(7) Homrighausen, E. 1958. Untersuchungen über die Aggregation von Böden und ihre Kennzeichnung durch Schlagfestigkeitsmessungen. Z. Acker-u. Pfl. bau 105: 61-88.

(8) Joffe, J. S. \& Zimmerman, M. 1945. Sodium, calcium, and magnesium ratios in the exchange complex. Soil Sci. Soc. Amer. Proc. 9: $51-55$.

(9) Катsснілsкi, N. A. 1957. Die Natur der mechanischen Stabilität und Wasserstabilität der Bodenstruktur. Probleme der Krümelstabilitätsmessung und der Krümelbildung. Wiss. Arbeitstagung, Berlin 10-11. Okt. 1957. Tagungsberichte 13: 139-149.

(10) Koslekov, P. N., Osipova, Z. M. \& TAnin, K. E. 1952. [The change of structure of heavy peatpodzolized soils in long-term experiments with fertilizers]. Pochvovedenie 820-828 (Ref. Soils Fert. 16: p. 29).

(11) LEvin, F. I. 1957. Water stability of the structure of sod-podzolic soils with application of lime and organic fertilizers. Ibid. 10: 98-104 (Ref. Soils Fert. 21: p. 100).

(12) Mazurak, A. P. 1953. Aggregation of colloidal clay from Hesperia sandy loam as affected by univalent and calcium ions. Soil Sci. 76: 181-191.

(13) Pallotta, U. 1957. La stabilita di struttura nei terreni della Sardegna in rapporto con alcune caratteristiche fisicochimiche. Agrochimica 1: 268-287 (Ref. Soils Fert. 20: p. 265).

(14) Purokosкi, P. 1959. Rannikkoseudun rikkipitoisista maista. Referat: Úber die schwefelhaltigen Böden an der Küste Finnlands. Agrogeol. publ. 74: 27 p.

(15) Ravikoviтch, S. \& Hagin, J. 1957. The state of aggregation in various soil types in Israel. Ktavim 7: 107-122 (Ref. Soils Fert. 20: p. 328).

(16) Robinson, D. O. \& PAge, J. B. 1950. Soil aggregate stability. Soil Sci. Soc. Amer. Proc. $15: 25-29$.

(17) SснаснтsснавеL, P. \& Hartge, K. 1958. Die Verbesserung der Strukturstabilität von Ackerböden durch eine Kalkung. Z. Pfl. Ern. u. Düng. 83: 193-202.

(18) SillanpäÄ, M. 1958. Soil Aggregation as determined by wet sieving method after different sample treatments. Selostus: Muruanalyysistä märkäseulontamenetelmällä. Acta agr. fenn. 94,16: $20 \mathrm{p}$.

(19) - 1959. Hydraulic conductivity of Finnish subsoils as related to some other soil physical properties. Selostus: Eräiden maan fysikaalisten ominaisuuksien vaikutuksesta pohjamaan vedenläpäisevyyteen. Agrogeol. publ. 73:28 p.

(20) - 1959. The influence of some physical soil properties on subsoil structure. Selostus: Eräiden maan fysikaalisten ominaisuuksien vaikutuksesta pohjanmaan rakenteeseen. Ibid. $75: 24 \mathrm{p}$.

(21) Vuorinen. J. 1939. Untersuchungen über die Koagulation des schweren Glazialtons. Selostus: Jäykän glasiaalisaven koagulaatiota koskevia tutkimuksia. Ibid. 50: $114 \mathrm{~s}$.

S E L O S T U:

\section{KATIONIEN VAIKUTUKSESTA MAAN RAKENTEESEEN}

Mikko Sillanpää

\section{Maantutkimuslaitos, Maatalouden tutkimuskeskus, Helsinki}

Maan rakenteen ominaisuuksien on todettu riippuvan paitsi maan lajitekoostumuksesta ja orgaanisesta aineksesta myös sen kemiallisista ominaisuuksista. Erityisesti kationien laatuun on kiinnitetty huomiota. Maakolloidien elektronegatiivisesta luonteesta johtuen anionien merkitys lienee vähemmän 
merkityksellinen, ja mm. N- ja P-käsittelyillä saadut muruisuuden lisäykset on selitetty-johtuvan epäsuorasti niiden aiheuttamien sadonlisäysten edullisesta vaikutuksesta maan orgaanisen aineksen määrään. Nykyisin käytettävät suuret kalkki- ja lannoitemäärät voivat melkoisesti muuttaa maan kemiallisia ominaisuuksia, mistä voi olla seurauksena muutoksia myös sen fysikaalisissa ominaisuuksissa mm. rakenteessa.

Kationien vaikutusten tutkimiseen käytettiin pääasiassa liejusavinäytteitä, mutta analyysejä suoritettiin vertailumielessä myös aitosavi-, hiesusavi- ja lietosavinäytteistä. Ilmakuiva maa esiseulottiin, sekä virheiden ja hajonnan pienentämiseksi kokeissa käytettiin vain tiettyjä murufraktioita (2.3$3.5 \mathrm{~mm}$ liejusavesta ja $1.3-2.0 \mathrm{~mm}$ muista savista). Ilmakuivat näytteet (25 g) kostutettiin kapillaarisesti käsittelyliuoksilla (kuva 1, A), annettiin seisoa liuoksiin upotettuna 2 vrk. ja kuivattiin samaa menetelmää käyttäen (kuva 1, B). Kuivatusta jatkettiin antamalla näytteiden seisoa avonaisissa astioissa. Homeenmuodostus ehkäistiin asettamalla voimakkaita lamppuja näytteiden yläpuolelle. Lämpötila kuivatuksen aikana pidettiin $28-31^{\circ} \mathrm{C}$ :na.

Näytteiden kostutuksessa käytettiin 0.01-n, $\mathrm{NaCl}-, \mathrm{KCl}-, \mathrm{MgCl}_{2}-, \mathrm{CaCl}_{2}-\mathrm{ja} \mathrm{HCl}$-liuoksia sekä tislattua vettä. Liejusavinäytteiden käsittelyssä olivat edellisten lisäksi mukana myös $\mathrm{FeCl}_{3}$ ja $\mathrm{AlCl}_{3}$ sekä kaikki liuokset 0.003-, 0.01-, 0.03-, 0.1: ja 0.3-normaalisina.

Viikon kuluttua näytteiden käsittelyn päättymisestä suoritettiin niistä muruanalyysit märkäseulontamentelmällä. Niiden tulokset on esitetty taulukoissa 1 ja 3 sekä liejusavea koskevat regressiot taulukossa 4 ja kuvassa 2. Eri käsittelyjen vaikutusten erojen tilastolliset merkitsevyydet on esitetty taulukossa 2 (AS) ja taulukossa 5 (LjS).

Aitosavessa ovat $\mathrm{HCl}$ - ja $\mathrm{CaCl}_{2}$-käsittelyt parantaneet murujen vedenkestävyyttä eniten. Niiden vaikutus on merkitsevästi parempi kuin muiden lukuunottamatta $\mathrm{MgCl}_{2}$-käsittelyjä (taulukko 2). $\mathrm{Myös}$ $\mathrm{Mg}$-käsittelyn vaikutus on parantanut murujen vedenkestävyyttä merkitsevästi $\mathrm{NaCl}$ - ja $\mathrm{H}_{2} \mathrm{O}$-käsittelyihin verrattuna.

Hiesu- ja lietosavissa ovat eri kationien vaikutukset samansuuntaiset kuin aitosavessa. Hiesusavessa eri käsittelyjen vaikutus ei saavuttanut tilastollista merkitsevyyttä ja lietosavessa se rajoittui vain $\mathrm{H}_{2} \mathrm{O}-\mathrm{CaCl}_{2^{-}}\left(\mathrm{t}=2.47^{*}\right), \mathrm{H}_{2}-\mathrm{HCl}-\left(\mathrm{t}=1.97^{*}\right)$ ja $\mathrm{NaCl}-\mathrm{CaCl}_{2^{-}}(\mathrm{t}=2.08 *)$ käsittelyihin.

Liejusavella suoritetuissa kokeissa todettiin yleispiirteenä kaikkien kationien auksi parantavan murujen vedenkestävyyttä käsittelyliuosten konsentraatioiden kasvaessa tiettyyn optimiin asti, jonka jälkeen niiden vaikutus alkoi pienentyä (taulukko 3 ja kuva 2). Suurimpien liuoskonsentraatioiden aiheuttamassa murujen vedenkestävyyden huononemisessa lienee kysymyksessä sama ilmiö, jonka MAzURAK (12) havaitsi aiheuttavan murujen heikkenemistä silloin, kun keinokasteluveden suolakokoomuksessa ja konsentraatiossa tapahtui muutoksia.

Eri kationien vaikutus näyttää saavuttavan optiminsa tässä maalajissa jonkinverran eri konsentraatioissa. $\mathrm{NaCl}: \mathrm{n}, \mathrm{HCl}: \mathrm{n}$ ja $\mathrm{MgCl}_{2}: \mathrm{n}$ optimikonsentraatiot ovat 0.01-normaalisuuden paikkeilla, $\mathrm{CaCl}_{2}: \mathrm{n}$ $0.01-0.03: \mathrm{n}$ ja $\mathrm{KCl}: \mathrm{n}, \mathrm{AlCl}_{3}: \mathrm{n}$ sekä $\mathrm{FeCl}_{3}: \mathrm{n} 0.03-0.1-\mathrm{n}$.

Alumiinin ja raudan vaikutus liejusaven murujen vedenkestävyyteen on selvästi voimakkaampi kuin muiden kationien. Kalsium ja magnesium poikkeavat toisistaan melko vähän, joskin magnesium näyttää alhaisemmissa konsentraatioissa parantavan murujen vedenkestävyyttä voimakkaammin, kun taas suuremmissa konsentraatioissa kalsiumin regressiokäyrä osoittaa vähemmän dispersiotaipumusta. Kaliumkloridikäsittely näyttää aiheuttaneen vähiten muutoksia murujen vedenkestävyydessä, mikä ilmenee KCl-käyrän huomattavasti muita lievemmåstä kaarevuudesta.

Mielenkiintoisena piirteenä voidaan todeta, että $\mathrm{HCl}: \mathrm{n}$ vaikutus liejusavessa on lähinnä saman tapainen kuin natriumin, joka kaikissa neljässä maalajissa on osoittautunut kationeista epäedullisimmaksi murujen vedenkestävyydelle. Tässä suhteessa $\mathrm{HCl}$ :n vaikutus muihin käsittelyihin verrattuna on olennaisesti erilainen kuin muissa savimaalajeissa. Todennäköistä onkin, että eri kationien vaikutus maan rakenteeseen riippuu suuresti muiden kationien määristä sekä käsittelyjen aiheuttamista kationinvaihtoprosesseista eri maissa. Tämä rajoittaa olennaisesti jollakin maalla saatujen tulosten yleistämistä ja soveltamista muihin maalajeihin. 